\title{
Analytical Enzymatic Saccharification of Lignocellulosic Biomass for Conversion to Biofuels and Bio-Based Chemicals
}

\author{
Madhavi Latha Gandla, Carlos Martín and Leif J. Jönsson *(1) \\ Department of Chemistry, KBC Chemical-Biological Centre, Umeå University, SE-901 87 Umeå, Sweden; \\ madhavi.latha.gandla@umu.se (M.L.G.); carlos.martin@umu.se (C.M.) \\ * Correspondence: leif.jonsson@umu.se; Tel.: +46-90-786-6811
}

Received: 8 October 2018; Accepted: 24 October 2018; Published: 27 October 2018

\begin{abstract}
Lignocellulosic feedstocks are an important resource for biorefining of renewables to bio-based fuels, chemicals, and materials. Relevant feedstocks include energy crops, residues from agriculture and forestry, and agro-industrial and forest-industrial residues. The feedstocks differ with respect to their recalcitrance to bioconversion through pretreatment and enzymatic saccharification, which will produce sugars that can be further converted to advanced biofuels and other products through microbial fermentation processes. In analytical enzymatic saccharification, the susceptibility of lignocellulosic samples to pretreatment and enzymatic saccharification is assessed in analytical scale using high-throughput or semi-automated techniques. This type of analysis is particularly relevant for screening of large collections of natural or transgenic varieties of plants that are dedicated to production of biofuels or other bio-based chemicals. In combination with studies of plant physiology and cell wall chemistry, analytical enzymatic saccharification can provide information about the fundamental reasons behind lignocellulose recalcitrance as well as about the potential of collections of plants or different fractions of plants for industrial biorefining. This review is focused on techniques used by researchers for screening the susceptibility of plants to pretreatment and enzymatic saccharification, and advantages and disadvantages that are associated with different approaches.
\end{abstract}

Keywords: lignocellulose; biomass; biofuel; sugar platform; pretreatment; enzymatic saccharification; cellulose; analytical scale; high-throughput screening

\section{Introduction}

The phase-out of fossil fuels in the transport sector is a major challenge that will require a combination of different measures including improved fuel efficiency, electrification, and increased production of conventional and advanced biofuels [1]. According to current assessments, production levels of advanced biofuels are not on track and major efforts are required in this area within the coming decade [1]. Especially with respect to long-range road transport, aviation, and marine transport, advanced biofuels can make a significant contribution to a shift from fossil-based energy to renewable energy.

The most wide-spread biofuel today is ethanol, with USA and Brazil being the two main producers, and corn grain and cane sugar being the two main feedstocks [2-4]. Apart from being widely used in fuels for Otto engines, ethanol, as ED95 fuel, is also useful for diesel engines [5]. Furthermore, ethanol can be valorized to hydrocarbons in AtJ (alcohol-to-jet) processes [6]. Thus, processes in which sugars are converted to ethanol, and perhaps further on to other energy carriers, are likely to play an important role in the biofuel sector also in the future. 
Sugars derived from lignocellulosic biomass can further boost the production levels of bioethanol and other bio-based energy carriers [7]. Lignocellulosic feedstocks include energy crops, softwood, hardwood, and agricultural residues (straw, corn stover, sugarcane bagasse, cassava stems, etc.). The three main constituents of dry lignocellulose are cellulose, hemicellulose, and lignin [8]. The cellulose and the hemicellulose can be hydrolyzed to monosaccharides in sugar-platform processes. The most common concept is based on an initial diminution step, for instance wood chipping, followed by pretreatment and enzymatic saccharification of the cellulose and residual hemicellulose remaining after the pretreatment (Figure 1). As lignocellulose is recalcitrant to biochemical conversion [8], the pretreatment is necessary to increase the susceptibility of the lignocellulose to enzymatic saccharification. Reducing recalcitrance is key to high-yield cost-effective bioconversion of lignocellulosic feedstocks. The sugar can be refined to biofuels by chemical catalysis or microbial fermentation. The most common microorganism used to ferment sugar is baker's yeast, Saccharomyces cerevisiae [9], as it typically will provide high ethanol yields from hexose sugars in rapid and robust industrial fermentation processes. Metabolic engineering can be used to further improve the characteristics of S. cerevisiae and other microbes of interest.

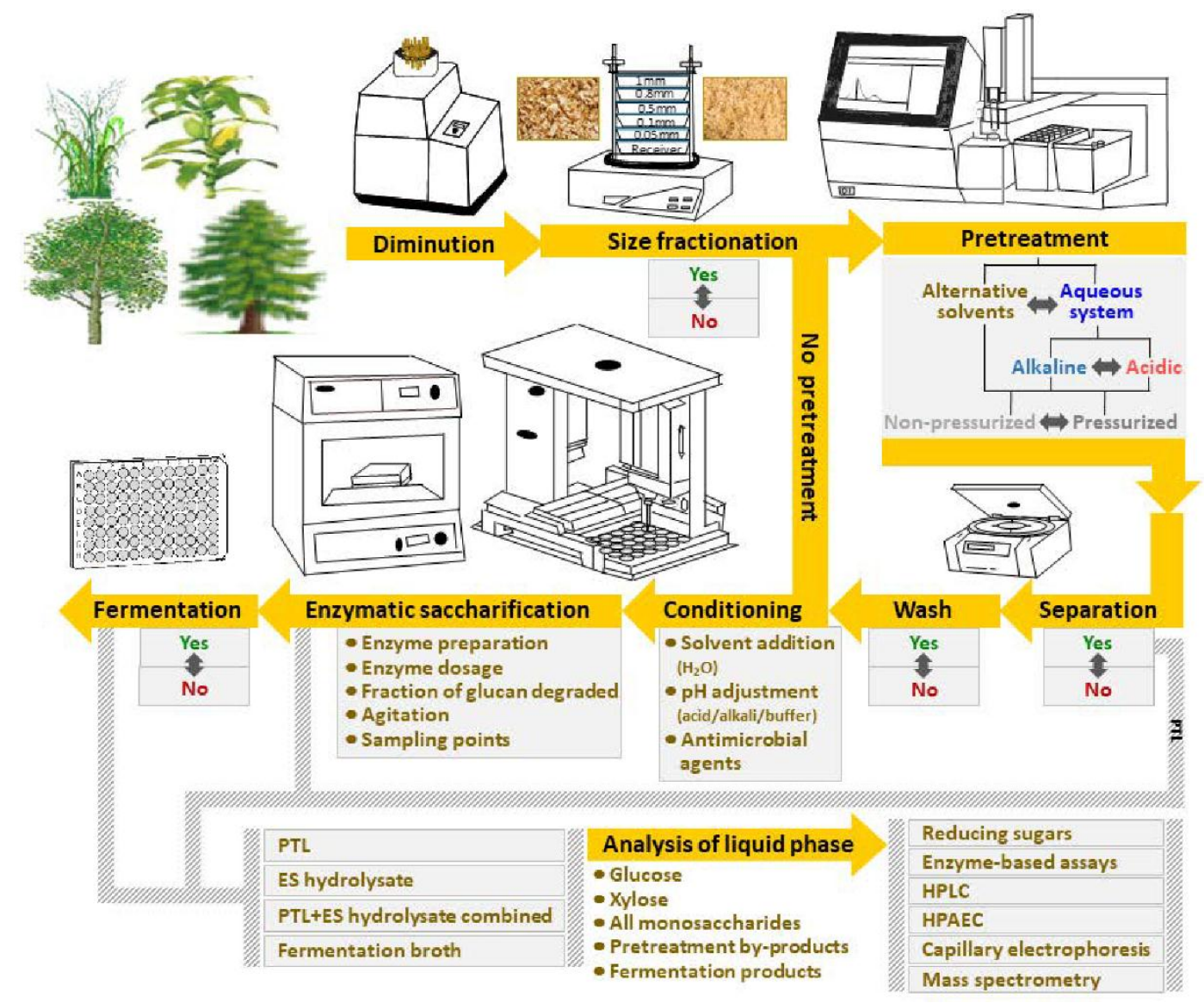

Figure 1. Schematic depiction of typical workflow of analytical enzymatic saccharification of lignocellulosic feedstocks.

Most scientific studies of sugar-platform processes are based on preparative saccharification of pretreated feedstock, i.e., the aim is to generate a maximum amount of sugar for a subsequent fermentation process while taking into account factors that affect process economy, such as enzyme loading, yield, and productivity. However, an increasing number of scientific studies are devoted to the concept analytical enzymatic saccharification, as outlined in Figure 1. Analytical enzymatic saccharification is used to evaluate a set of feedstock samples, a set of pretreatment methods, or a set of enzyme preparations. The aim is not exhaustive saccharification as in preparative studies, but rather 
to detect differences in the susceptibility to enzymatic saccharification. If, on one hand, the enzymatic saccharification of cellulose is driven too far, it might be difficult to detect differences in susceptibility to cellulolytic enzymes. If, on the other hand, the enzymatic saccharification is superficial and the fraction of cellulose converted is very low, it might be difficult to correctly assess the value of the differences, as one fraction of the cellulose is typically easy to degrade while other fractions are more difficult for the enzymes to access and hydrolyze [10]. Thus, it is best to convert a substantial fraction of the cellulose, but not so much that the differences between the analyzed materials become indistinct. Since it is an analytical procedure, factors such as enzyme loading, yield, and productivity become less important in comparison to preparative enzymatic saccharification.

The aim of this review is to compare different approaches that have been employed for analytical enzymatic saccharification of lignocellulosic biomass, and to highlight advantages and disadvantages with different approaches. While some scientific studies in this area have focused on sets of natural varieties of lignocellulosic feedstocks, a growing number of studies are devoted to analysis of engineered plants [11]. These studies demonstrate how rather small differences in constituents such as hemicellulose, lignin, and pectin can have a major impact on the saccharification efficiency. However, the techniques used to evaluate such plants differ substantially, for example with regard to size fractionation, pretreatment technology, pretreatment conditions, separation of solid and liquid phases, conditions for enzymatic saccharification, and analyses (Figure 1), and this review will pinpoint and explain the consequences of such differences.

\section{Lignocellulosic Feedstocks}

The proportions of the main organic constituents of lignocellulosic feedstocks, i.e., cellulose, hemicelluloses, and lignin, differ widely in different species of plants [12,13]. It is noteworthy that apart from cellulose, which is a uniform component of most types of lignocellulosic biomass, the composition of the other main constituents exhibits major quantitative and qualitative differences for lignocellulose of different origin.

Cellulose, the structural base of the plant cells, is a polysaccharide composed of anhydroglucose units linked by $\beta-(1 \rightarrow 4)$-glycosidic bonds arranged linearly, and reaching a degree of polymerization (DP) of up to 15,000 . Cellulose macromolecules are organized in a compact arrangement, where individual chains form rigid microfibrils that are stabilized by hydrogen bonds. The direct consequence of that arrangement is a highly crystalline macromolecular structure with a low reactivity towards most chemicals and solvents [12]. Alternating with the predominant crystalline domains, native cellulose contains also amorphous regions, which represent a minor part of the macromolecule, but are important targets for different reactants, including derivatization reagents as well as hydrolyzing chemicals and enzymes [14].

Hemicelluloses are composed of units of both hexoses and pentoses, which are arranged as relatively short (DP ranging between 50 and 200) $\beta$-(1 $\rightarrow 4$ )-linked chains that are often branched. Xylose, glucose and mannose units, and to a minor extent galactose and glucuronic acid units, constitute the backbone of most of the hemicelluloses, whereas arabinose and rhamnose units, as well as some non-carbohydrate moieties, form the branches. Hemicelluloses have different composition depending on the biomass source. O-Acetyl-galactoglucomannans and arabino-4-O-methylglucurono-D-xylans are the main hemicelluloses of softwood species, while $O$-acetyl-4-O-methylglucurono-D-xylans and arabino-(O-acetyl-4-O-methylglucurono)-D-xylans are predominant, respectively, in hardwood and herbaceous plants $[12,15]$. Hemicelluloses are a main contributor to the recalcitrance of lignocellulosic biomass. Differently to cellulose, hemicelluloses are relatively reactive, and prone to undergo hydrolysis under mild conditions.

Lignin is an aromatic polymer consisting of phenylpropanoid units linked by ether and carbon-carbon bonds forming a complex three-dimensional network [12]. As for hemicelluloses, the content and composition of lignin vary depending on the type of feedstock. Softwoods generally contain more lignin than hardwoods. Softwood lignin is composed almost exclusively of guaiacyl units, 
whereas hardwood lignin also contains syringyl units. Grass lignin contains $p$-hydroxyphenyl units, in addition to guaiacyl and syringyl units. Lignin binds together the components of lignocellulose, ensuring the structural integrity of the cell wall, and at the same time contributing to its recalcitrance to bioconversion. Therefore, lignin removal is one way of facilitating enzymatic hydrolysis of cellulose.

Other constituents of lignocellulosic feedstocks include extractives and minerals [12], both of which are typically present in small quantities. The extractives are heterogeneous in composition and chemical functionality, and they have in common that they can be removed by solvent extraction. Mineral constituents are present in small amounts in wood, but some gramineous crops contain larger quantities. A high mineral content can affect the buffering capacity of the medium, and, consequently, the operational conditions in lignocellulose processing.

In order to become useful for processing industry, lignocellulosic feedstocks have to be deconstructed to simpler substances that can be transformed to biofuels and other valuable bio-based products. Biochemical conversion, with enzymatic saccharification of cellulose as the core process, is a selective approach for deconstructing biomass to sugars that can then be channeled to the desired end products [16]. However, biochemical conversion is hindered by the inherent recalcitrance of lignocellulosic feedstocks. The recalcitrance to bioconversion is mainly a result of mechanisms evolved by plant biomass for resisting attacks on its structural components, and it is based on several features, such as the chemical composition and physical structure of the cell wall, cellulose structure, and changes induced by the industrial processing [17].

Lignocellulose recalcitrance is to a high extent governed by compositional particularities of the plant cell wall. The interference by lignin and hemicelluloses, which are intimately associated with cellulose fibrils in the lignocellulosic matrix, is a major factor contributing to the biomass recalcitrance. Although lignin content has been considered to be one of the main obstacles for cellulose enzymatic hydrolysis, a recent report points towards a more crucial role of lignin composition, in particular the content of syringyl and guaiacyl units and the amount of aryl ether linkages, as a key impediment for access of enzymes to the polysaccharides [18]. The capacity of lignin and pseudo-lignin, a product of carbohydrate degradation during thermal processing, to non-productively bind cellulases is another factor contributing to biomass recalcitrance [19]. Together with lignin, hemicelluloses and their acetyl groups also play an important role in retarding enzymatic conversion of cellulose. It was recently shown that strong cellulose-hemicellulose associations formed during biomass processing at high temperatures can reduce cellulose access more than the intrinsic hemicellulose present in the plant cell wall [20].

However, the recalcitrance of lignocellulosic feedstocks to bioconversion cannot be explained by looking only at chemical factors. Lignocellulose recalcitrance is also to a high extent caused by structural features [21]. The degree of polymerization and crystallinity of cellulose, as well as biomass porosity, specific surface area and particle size are factors contributing to the recalcitrance of lignocellulosic biomass to enzymatic saccharification $[8,17]$. In a recent study, a systematic comparison of three different wood species revealed that without pretreatment the structural factors were more important than the chemical composition and the cellulose crystallinity for explaining the differences in recalcitrance towards enzymatic saccharification [21].

\section{Pretreatment for Enzymatic Saccharification}

Pretreatment removes or weakens the barriers causing recalcitrance in such a way that the raw feedstock turns into a substrate that is amenable for enzymatic saccharification. There are many different pretreatment methods, and although some of them can be performed at low temperature, as a rule the most efficient approaches include heating. In general, lignocellulose bioconversion can be seen as a processing sequence basically including a high-temperature pretreatment step and a low-temperature enzymatic hydrolysis step.

A technically effective pretreatment should result in a high enzymatic digestibility of the cellulose contained in the pretreated solids, and a high recovery of hemicellulosic sugars/oligomers in the liquid 
fraction with a minimal formation of inhibitors of microbial and enzymatic processes [22]. Removal of hemicelluloses or their acetyl groups, disrupting the lignin sheath, decreasing the crystallinity and degree of polymerization of cellulose or increasing the porosity of the substrates are some of the mechanisms behind the enhancement of enzymatic digestibility by different pretreatments [23]. To be economically attractive, the pretreatment should allow handling high solids loads with minimal energy demand and low capital and operational cost [24]. The most industrially mature pretreatment methods are thermochemical processes, in which lignocellulosic feedstocks are mixed with an aqueous medium, either in liquid state or as steam, alone or in the presence of an impregnating chemical, and then subjected to a high-temperature treatment. Hydrothermal processing, either alone or with dilute acid or reinforced by steam explosion, and mild alkaline pretreatments are among the best-known thermochemical methods of interest for industrialization of bioconversion processes. Some methods developed in the pulping industry also have potential for large-scale application. There are also some pretreatment approaches that are of high academic interest, but that are still rather far from being mature for commercial application. An overview of some of the most relevant to date methods is presented in Table 1, and some details are discussed below.

Hydrothermal processing is an effective and technologically-mature pretreatment method, which can be implemented following several approaches, and it has been proven for many different lignocellulosic feedstocks. In the most basic hydrothermal pretreatment (HPT) approach, which is known also as liquid hot water pretreatment, autohydrolysis, and hydrothermolysis [25], the raw material is suspended in water, which by means of high pressure is forced to remain in liquid state at temperatures around $200^{\circ} \mathrm{C}$ for a certain time. Under those conditions, the hydronium ions resulting from water auto-ionization and from organic acids catalyze the solubilization of hemicelluloses, which are removed to a high extent without being largely hydrolyzed (Table 1). Simultaneously, lignin is relocalized on the biomass surface, cellulose is hydrated, and the pore size of the fibers is enlarged. All those phenomena result in an increase of the surface area available for enzyme penetration and, consequently, the potential of cellulose saccharification is largely improved. Advantages include that there is no use of chemical additives and no requirement of expensive anticorrosion materials. The effects on hemicelluloses are, however, rather limited, and the method has been used primarily for less recalcitrant forms of lignocellulose. Although the commercial-scale operation of HPT-based plants is not yet a reality, the technology has been successfully demonstrated in the production of ethanol, lignin pellets and molasses from wheat straw by the companies Inbicon and Dong Energy in their demonstration-scale biorefinery in Kalundborg, Denmark.

Hydrothermal pretreatment with dilute acid (HPT-DA), also known as dilute-acid pretreatment or dilute-acid prehydrolysis, is a method of uppermost relevance for industrial implementation. It is performed by mixing biomass with a diluted acid, commonly sulfuric acid below $2 \%(w / w)$, and heating the suspension to around $200{ }^{\circ} \mathrm{C}$ for a short time [23]. For some applications it is also effective to run the process at lower temperatures combined with longer residence times. HPT-DA efficiently removes hemicelluloses by almost complete hydrolysis to sugars. HPT-DA typically leads to some increase of the crystallinity of the material. A small portion of the lignin is also removed, even though severe conditions can lead to an apparent increase due to pseudo-lignin formation. In spite of the increase of the crystallinity of cellulose, HPT-DA results in a strong improvement of cellulose convertibility due to increased surface area and pore accessibility, hemicellulose solubilization, and shrinking of lignin through coalescence [26]. Although HPT-DA has some weaknesses regarding the requirement for the materials that are used for manufacture of reactors and the formation of inhibitory by-products, its effectiveness, technical straightforwardness, and technological readiness make it one of the most attractive choices for large-scale projects. The classical dilute-acid technology and/or other acid-based pretreatment approaches are implemented in most of the current commercial plants and demonstration projects for the development of cellulosic ethanol and biorefineries [27].

Another leading technology is hydrothermal pretreatment with steam explosion (HPT-SE), which consists of heating the feedstock with superheated steam to around $200{ }^{\circ} \mathrm{C}$ for a certain time 
and then depressurizing the system by a rapid discharge using a quick-action valve. The operation temperature and the holding time can vary depending on the nature of the feedstock. During the pretreatment, in which chemical and physical effects are combined, the plant cell wall structure is disrupted by the steam, and the hemicelluloses are solubilized/hydrolyzed to different extent depending on the operational conditions and on the presence of chemical additives. HPT-SE can be performed with no addition of chemicals, and in that case, as in the basic HPT, the process is catalyzed by autohydrolysis, but it can also be assisted by impregnation with external agents, such as $\mathrm{SO}_{2}, \mathrm{H}_{2} \mathrm{SO}_{4}$, or $\mathrm{NaOH}$. When $\mathrm{SO}_{2}$ or $\mathrm{H}_{2} \mathrm{SO}_{4}$ are used, hemicelluloses are hydrolyzed in the same way as in dilute-acid pretreatment, while the use of $\mathrm{NaOH}$ leads to solubilization of hemicellulosic oligomers without major hydrolysis. If no chemicals are added, the $\mathrm{pH}$ drops due to the release of acetic acid and uronic acids, and there is some resemblance with the acid-catalyzed process. Lignin is only slightly removed but, due to melting and depolymerization/repolymerization reactions, it undergoes redistribution over the cell wall leading to a higher exposure of cellulose fibres [23]. As a result of removal of hemicelluloses and redistribution of lignin, the accessibility of enzymes to cellulose is enhanced, which leads to a high degree of saccharification using relatively low loading of cellulases. The enzymatic convertibility can further be improved if the pretreated solids are subjected to delignification, for instance by an alkali treatment, before the addition of cellulases. Since HPT-SE is effective for a wide variety of bioresources ranging from herbaceous crops to highly recalcitrant softwood feedstocks, it is an attractive option for commercial application, and there are ongoing upscaling attempts by several companies in different countries (Table 1).

Mild alkaline pretreatment methods are performed with $\mathrm{NaOH}$ or other bases, which catalyze the saponification of the ester bonds crosslinking hemicelluloses and lignin, and cellulose peeling reactions. As a result, a large part of lignin is removed, cellulose is depolymerized and its digestibility is improved. Hemicelluloses are partially solubilized, but to a lower degree than in acid and autohydrolytical pretreatments (Table 1). Also some of the mild alkaline methods are modifications of hydrothermal processing, and can be seen as hydrothermal pretreatments with alkali (HPT-Al). In general, they require milder conditions than those used in the aforementioned HPT methods, and in some cases they can be run at room temperature. Apart from processes using strong alkalis, lime pretreatment, ammonia recycle percolation (ARP), and aqueous ammonia soaking (AAS) are promising technologies [28].

In addition to ARP and AAS, which are typical mild alkaline pretreatments, ammonia can also be used in AFEX (ammonia fiber expansion), a rather different processing approach. In AFEX, lignocellulose is heated with liquid ammonia, and the pressure of the system is first increased as result of ammonia volatilization, and then decreased by a sudden release in a comparable way as in HPT-SE. The effect of the high-pressure ammonia on biomass, combined with the explosive discharge, results in decrystallization of cellulose, prehydrolysis of hemicellulose, and modification of the lignin structure. Neither lignin nor hemicelluloses are solubilized, but their distribution is altered after extraction/redeposition phenomena, and that increases the porosity of the cell wall and the enzyme accessibility (Table 1). Some strengths of AFEX are the low biomass degradation, the almost complete recovery of the pretreatment chemical, and no requirement of washing prior to enzymatic hydrolysis or of addition of nutrients to the fermentation [29]. The weaknesses include that it is a capital-intensive process, it has a high energy requirement in the ammonia recovery step, and it is not effective for feedstocks with high lignin content [28].

Based on traditional chemical pulping processes, some pretreatment methods of commercial interest have been proposed. The BALI ${ }^{\mathrm{TM}}$ (Borregaard Advanced Lignin) process and the SPORL (Sulfite Pretreatment to Overcome Recalcitrance of Lignocellulose) process, which are both based on sulfite pulping, are two examples. These methods remove most of the lignin and variable amounts of hemicelluloses depending on the $\mathrm{pH}$ and temperature. By taking advantage of the existing infrastructure and knowledge in the pulping industry, the sulfite-based pretreatment processes have a great potential for commercialization [30]. The BALI ${ }^{\mathrm{TM}}$ pretreatment has been verified by Borregaard 
in a demonstration plant in Sarpsborg, Norway (Table 1). Chemical pulping processes, which primarily target lignin, result in a pretreated material that is amenable to enzymatic digestion, but drawbacks include high capital costs and the use of large amounts of chemical additives.

Using organic solvents, such as alcohols and organic acids, was initially investigated as an unconventional pulping alternative. It has developed into organosolv pretreatment, which relies on penetration of the solvent into lignocellulose pores to promote physical deconstruction and thus providing improved accessibility to the cellulose. As other chemical pulping methods, the organosolv process causes extensive delignification. Different degrees of solubilization of hemicelluloses can be achieved depending on the operational conditions. Cellulose is partially depolymerized and decrystallinized, and its susceptibility to enzymatic hydrolysis is improved. To be effective, organosolv pretreatment requires an operating temperature above $200{ }^{\circ} \mathrm{C}$, but if the process is catalyzed, for instance by an acid, it can be run at much lower temperatures. Since the cost of the solvents is an important issue for industrial applications, recycling is required for reducing operational costs [31]. However, the possibility of producing valuable by-products from the isolated high-quality lignin can possibly offset the high cost of the operations with solvents. The potential of organosolv pretreatment for industrial application has been investigated in pilot plants, such as those operated by Lignol and Chempolis (Table 1).

Other developments based on experience from the pulping industry have led to the use of oxidants, such as ozone, oxygen, or hydrogen peroxide, for removing lignin and thus pretreat lignocellulose for enzymatic saccharification [23]. The oxidants disrupt the lignin-carbohydrate association, cause some solubilization of hemicelluloses, and reduce cellulose crystallinity. Oxidative methods are usually combined with other methods, and although they are generally performed at moderate temperatures, the range of operational conditions can be rather wide depending on the method they are combined with, and sometimes operations close to $200^{\circ} \mathrm{C}$ can be required.

The potential of ionic liquids (ILs), organic salts that remain in liquid state below $100{ }^{\circ} \mathrm{C}$, for pretreatment of lignocellulosic materials has been intensively investigated during the last years. Because of their excellent dissolution performance, high chemical and thermal stability, and the fact that they are non-flammable, ILs are considered attractive green solvents for cellulose. Upon solubilization in ILs and further regeneration from the solution, cellulose turns into a material with high surface area, low crystallinity, reduced interference by lignin and hemicelluloses, and consequently with improved enzymatic hydrolysis efficiency. The capability of the IL to disorder the cell wall structure has been found to be an important factor governing its effect on recalcitrance [32]. Analysis of mass balances indicate that substantial fractions of the lignocellulosic feedstocks are often lost during IL pretreatment $[32,33]$. Furthermore, the high cost for producing the ILs and for recovering them after pretreatment, together with the energy required for homogenization are challenges to be faced in order to meet the demands for large-scale application [34].

There has been a lot of discussion about physical and biological pretreatment methods, which indeed have interesting features regarding their effects on biomass recalcitrance, but their development as independent pretreatment methods is limited by serious drawbacks. Physical pretreatment methods include mechanical disintegration and irradiation. They lead to structural disruption and reduction of the particle size and crystallinity of the raw material, which results in some improvement of the enzymatic digestibility. However, since the energy requirements for achieving high cellulose conversion are far too high, these methods are of interest only if used in combination with other techniques or as a preparative step before other processes are applied [35]. In biological pretreatment, the ligninolytic enzyme system of lignin-degrading microorganisms, especially white-rot fungi, is used to remove lignin from lignocellulose. Advantages include low energy consumption and capital costs. However, due to the slow rate, biological pretreatment is relevant only if combined with other methods or with storage prior to other forms of pretreatment [36]. 
Table 1. Overview of common pretreatment methods.

\begin{tabular}{|c|c|c|c|c|c|c|c|}
\hline Method & $\begin{array}{l}\text { Typical Temperature } \\
\text { and Reaction Time }\end{array}$ & Chemicals & $\begin{array}{c}\text { Effects on } \\
\text { Hemi-Celluloses }\end{array}$ & Effects on Lignin & Effects on Cellulose & Examples of Upscaling Attempts & Ref. \\
\hline $\begin{array}{c}\text { Hydrothermal } \\
\text { pretreatment }\end{array}$ & $\sim 170-230^{\circ} \mathrm{C}, 10-30 \mathrm{~min}$ & None & $\begin{array}{c}\text { Partial } \\
\text { solubilization }\end{array}$ & Slight removal & Slight crystallinity increase & Inbicon (Denmark) & [25] \\
\hline $\begin{array}{l}\text { Hydrothermal } \\
\text { pretreatment with } \\
\text { dilute acid }\end{array}$ & $\begin{array}{c}\sim 120-230^{\circ} \mathrm{C} \\
\text { from a few sec to } \sim 1 \mathrm{~h}\end{array}$ & $\begin{array}{l}\mathrm{H}_{2} \mathrm{SO}_{4}, \mathrm{HCl} \\
\mathrm{H}_{3} \mathrm{PO}_{4} \\
\text { organic acids }\end{array}$ & $\begin{array}{l}\text { Complete } \\
\text { hydrolysis }\end{array}$ & $\begin{array}{l}\text { Disruption and } \\
\text { redistribution, } \\
\text { slight removal }\end{array}$ & $\begin{array}{l}\text { Partial depolymerization, } \\
\text { slight crystallinity increase }\end{array}$ & $\begin{array}{c}\text { Iogen-Raízen (Brazil), POET-DSM } \\
\text { (USA), Iogen (Canada), } \\
\text { Blue Sugars (USA) }\end{array}$ & {$[23,26,27]$} \\
\hline $\begin{array}{l}\text { Hydrothermal } \\
\text { pretreatment with } \\
\text { steam explosion }\end{array}$ & $\begin{array}{l}\sim 160-230{ }^{\circ} \mathrm{C} \\
\sim 1-30 \mathrm{~min}\end{array}$ & $\begin{array}{c}\text { None, } \mathrm{SO}_{2}, \mathrm{H}_{2} \mathrm{SO}_{4} \\
\mathrm{H}_{3} \mathrm{PO}_{4}, \mathrm{NaOH}\end{array}$ & $\begin{array}{l}\text { Partial to complete } \\
\text { solubilization, } \\
\text { de-acetylation }\end{array}$ & $\begin{array}{l}\text { Slight removal and } \\
\text { modification }\end{array}$ & Slight crystallinity increase & $\begin{array}{c}\text { Sekab (Sweden), Abengoa (Spain), } \\
\text { Beta Renewables (Italy), Verenium } \\
\text { (USA), Greenfield (Canada) }\end{array}$ & {$[23,24,27]$} \\
\hline Mild alkaline methods & $\begin{array}{l}\sim 25-180^{\circ} \mathrm{C} \text {, from a few } \\
\text { min to several weeks }\end{array}$ & $\begin{array}{c}\mathrm{NaOH}, \mathrm{KOH}, \\
\mathrm{Ca}(\mathrm{OH})_{2}, \mathrm{NH}_{4} \mathrm{OH}\end{array}$ & $\begin{array}{c}\text { Partial } \\
\text { solubilization, } \\
\text { deacetylation }\end{array}$ & $\begin{array}{l}\text { Significant } \\
\text { removal }\end{array}$ & $\begin{array}{l}\text { Crystallinity decrease, } \\
\text { depolymerization }\end{array}$ & DuPont Danisco (USA) & {$[28]$} \\
\hline AFEX & $\begin{array}{l}40-100{ }^{\circ} \mathrm{C}, \\
5-45 \min \end{array}$ & $\mathrm{NH}_{3}$ & Deacetylation & Structural changes & Crystallinity decrease & DEINOVE-MBI (USA) & {$[28,29]$} \\
\hline $\begin{array}{l}\text { Chemical pulping } \\
\text { (Kraft, sulfite, soda, } \\
\text { or organosolv) }\end{array}$ & $90-250^{\circ} \mathrm{C}, 30-60 \mathrm{~min}$ & $\begin{array}{l}\text { Depends on } \\
\text { process }\end{array}$ & Variable removal & Extensive removal & $\begin{array}{l}\text { No removal, but degree of } \\
\text { polymerization and } \\
\text { crystallinity affected }\end{array}$ & $\begin{array}{l}\text { Borregaard (Norway), Lignol } \\
\text { (Canada), Chempolis (Finland) }\end{array}$ & {$[30,31]$} \\
\hline Oxidative methods & $\begin{array}{l}\text { From room temperature } \\
\text { to } \sim 200^{\circ} \mathrm{C}\end{array}$ & $\mathrm{O}_{3}, \mathrm{O}_{2}, \mathrm{H}_{2} \mathrm{O}_{2}$ & Partial removal & $\begin{array}{l}\text { Significant } \\
\text { removal }\end{array}$ & $\begin{array}{l}\text { Partial depolymerization, } \\
\text { marginal crystallinity increase }\end{array}$ & BioGasol (Denmark) & [23] \\
\hline Ionic liquids & $\sim 80-130{ }^{\circ} \mathrm{C}$ & Ionic liquids & Solubilization & Solubilization & Decrystallization & ? & [32-34] \\
\hline
\end{tabular}




\section{Enzymatic Saccharification of Lignocellulosic Feedstocks}

Enzyme preparations that are used for saccharification of lignocellulosic feedstocks contain a large number of different enzymes that act in synergy to degrade cellulose to sugar [37]. The most studied microbial producer of cellulolytic and hemicellulolytic enzymes is the ascomycete Trichoderma reesei (teleomorph Hypocrea jecorina) [38]. Analysis using two-dimensional gel electrophoresis revealed the identity of 52 protein spots in the extracellular medium of T. reesei, and more than 300 protein spots were observed [39]. Another proteomics study covered the quantification of 230 extracellular T. reesei proteins [40]. These studies exemplify the complexity of extracellular enzyme preparations used for degradation of lignocellulose.

Enzymes that have commonly been recognized to be involved in the degradation of cellulose to glucose include the hydrolases cellobiohydrolase, endoglucanase, and $\beta$-glucosidase (cellobiase) [37]. Cellobiohydrolases split off cellobiose from the ends of cellulose chains, whereas endoglucanases create a larger number of cellulose chain ends by hydrolysis of glycosidic linkages in the interior of the chains. $\beta$-Glucosidase hydrolyzes cellobiose to glucose. More recently, oxidoreductases have also been found to play a role in enzymatic saccharification of cellulose. Although its role in wood biodegradation is not yet fully understood, lytic polysaccharide monooxygenase (LPMO) can assist other cellulolytic enzymes by disrupting crystalline cellulose in a reaction driven by molecular oxygen $[41,42]$. Thereby the cellulose is made more accessible to other enzymes.

As xylans are typically the quantitatively most important type of hemicelluloses in agricultural residues and in hardwood, many enzyme preparations used for saccharification of lignocellulose also contain xylanases, xylosidases, and acetyl esterases. Xylanase-rich enzyme preparations are sometimes added separately to boost the hydrolysis of xylan-rich feedstocks (Table 2). However, xylan is more susceptible to acid hydrolysis than is cellulose, and it is the hemicelluloses that are the main target for hydrothermal pretreatment under acidic conditions. If acid catalysts such as sulfuric acid and sulfur dioxide are included in the pretreatment, the result may be almost quantitative degradation of the hemicellulose, even for the most recalcitrant forms of lignocellulose, such as softwood [43]. Therefore, the effects of adding hemicellulases to the reaction mixture are related to both the feedstock and the type and the severity of the pretreatment.

Enzymatic saccharification of biomass often relies on commercial enzyme preparations. One of the commercial cellulolytic enzyme preparations that have been most used in scientific studies, Novozymes' Celluclast $1.5 \mathrm{~L}$, is based on enzymes from T. reesei. As Celluclast $1.5 \mathrm{~L}$ contains relatively low $\beta$-glucosidase activity, it has often been supplemented with Novozym 188 (Table 2), a $\beta$-glucosidase-rich enzyme preparation derived from the ascomycete Aspergillus niger. Enzyme preparations developed more recently typically contain sufficient quantities of $\beta$-glucosidase activity to use without further supplementation.

The enzyme dosages vary widely depending on the purpose of the enzymatic saccharification. Enzyme loading descriptions include activity assays, such as filter paper units (FPUs) and CMCase (carboxymethyl cellulase) activity, mg enzyme protein per g glucan or per g (DW, dry weight) biomass, as well as simple gravimetric or volumetric loadings. With regard to gravimetric and volumetric loadings, it is important to keep in mind that most commercial enzyme preparations are provided in liquid form and mainly consist of solvent and additives. For example, the protein content of Celluclast $1.5 \mathrm{~L}$ and Novozym 188 has been reported to be 4.0 and $5.1 \%(w / v)$, respectively [44].

The enzymatic saccharification step is typically performed for $24-72 \mathrm{~h}$ at a temperature of $45-50{ }^{\circ} \mathrm{C}$, at a $\mathrm{pH}$ of around 5, and with agitation (Table 2). Sometimes, additives such as antimicrobial agents and surfactants are used (Table 2). As the reaction mixtures are typically not aseptic, antimicrobial agents are used to prevent sugar consumption by bacterial contaminants. Certain surfactants, such as Tween 20, have been found to improve enzymatic saccharification of cellulose [45]. 
The increased sugar concentration resulting from enzymatic saccharification is not a linear function of the time. Jeoh et al. recently reviewed the literature on kinetics of enzymatic saccharification of cellulose, and concluded that further studies are needed to develop a mechanistic model that accurately predicts the time course of the reaction [46]. Typical batchwise saccharification processes are characterized by a three-phase curve consisting of an initial rapid phase targeting easily accessible cellulose, an intermediate phase with moderate hydrolysis rate targeting cellulose that is more difficult to access, and a final slow phase targeting recalcitrant cellulose [10]. By the end of the intermediate phase, about $70 \%$ of the initial quantity of cellulose has been hydrolyzed [10]. Preparative enzymatic saccharification typically aims at conversion of $\geq 70 \%$ of the glucan of the feedstock, since the sugar yield is a critical factor in biochemical conversion. As the purpose of analytical saccharification is to reveal differences in susceptibility rather than to achieve a high sugar yield, the reaction is often not allowed to proceed as far as to $\geq 70 \%$ glucan conversion. In most cases, only the end value, the sugar yield, is reported. To better capture the complexity of cellulose degradation, samples are sometimes taken both during the reaction (for determination of the glucose production rate) and at the end of the reaction (for determination of the glucose yield) e.g., [47,48].

\section{Analytical-Scale Pretreatment and Enzymatic Saccharification}

\subsection{Pretreatment and Enzymatic Saccharification}

Research laboratories with focus on assessment of lignocellulosic feedstocks for biofuel production use analytical enzymatic saccharification to screen large sets of samples. Figure 1 and Table 2 provide an overview of different approaches to analytical-scale saccharification [43,47-73]. The main intention of analytical-scale studies is to use small amounts of biomass to screen many samples and parameters, for example with regard to comparison of different feedstocks, genetic modifications, environmental variants, different parts of plants, and different pretreatment methods. The selection of approach depends on the type of feedstock and the cell wall composition, the recalcitrance, the amount of material available for analysis, the number of biomass samples to be screened, the level of detailed information emanating from the experiments, etc. Semi-automated and HTP (high-throughput)-based methods often cover both enzymatic saccharification without pretreatment and combined pretreatment and enzymatic saccharification (Figure 1). Some of these approaches are based on robotic platforms starting from the diminution step and further on all the way to analysis of the products obtained after saccharification or fermentation (Figure 1, Table 2).

The first step is particle size reduction to facilitate uniform dispersion of biomass to vials or microplates in a reproducible manner (Figure 1). The sample size in these assays usually varies from a few $\mathrm{mg}$ to several $\mathrm{g}$ (Table 2). Because of the small sample size even a slight variation in the experimental process will have significant impact on the outcome. Diminution has been achieved using Wiley knife mills (Thomas Scientific, Swedesboro, NJ, USA), ZM 200 centrifugal mills (Retsch, Haan, Germany), and MM400 bead mills (Retsch). Robotic platforms for biomass grinding and dispersion have also been used [62-64]. A few studies (Table 2) have included a size fractionation step (Figure 1) that provides a defined size interval by using sieving systems, such as the AS 200 (Retsch). As the rate of enzymatic saccharification is dependent on the surface area of the particles, it is advantageous to utilize a well-defined material. Many studies have been performed using particle sizes in the range 0.1-1.0 mm (20-80 mesh size) (Table 2). One investigation has been based on poplar handsheets that were punched into small disks of uniform thickness mimicking filter paper discs [65]. Pulping, preparation of hand sheets and disks, and dispensation of the disks into microtiter plate wells is labor intensive and time consuming, but useful for screening of enzyme mixtures. As yield calculations are typically based on the DW, drying and moisture content analysis is typically a part of the operations. 
The next step is selection of equipment and conditions for pretreatment (Figure 1). Pretreatment equipment that has been used for analytical enzymatic saccharification include both non-pressurized and pressurized systems. Non-pressurized systems include water baths $[64,66]$ and heat blocks [62,63], and typical temperatures are in the range 80-90 ${ }^{\circ} \mathrm{C}$ (Table 2). Pressurized systems include autoclaves [61,67], ASE 350 Accelerated Solvent Extractor (Dionex, Sunnyvale, CA, USA) [68], Parr reactors (Parr Instrument Company, Moline, IL, USA) $[65,69,70]$, single-mode microwave systems [54-59] (Table 2), and partially or fully automated robotic systems for 96-well plate format [46-50] (Table 2). One investigation has been based on transparent plastic microtiter plates for solvation of biomass using ionic liquids where biomass dissolution was determined by measuring scattered light [74]. Studer et al. [51,52] used a pressurized steam-chamber reactor with a Hastelloy 96-well format insert with individual metal cups with automated dispension. Selig et al. [70] used a similar approach, with 96-well metal plates in SBS (Society for Biomolecular Screening) format instead of individual cups, where the plates could be stacked in the reactor to handle large sets of samples in one run. In both these cases the 96-well plates were made of metal to withstand high temperatures and dilute-acid pretreatment.

Most analytical-scale studies have been based on HPT using either steam, dilute acid, or dilute alkali (Table 2). In these cases, HPT was performed in pressurized chambers including autoclaves, robotic single-mode microwave systems, steam chambers (custom-made for quick heating and cooling), and Parr reactors. Alkaline pretreatment with sodium hydroxide has been performed using non-pressurized systems, such as heating blocks [62,63] and waterbaths [64]. Pretreatment with ionic liquids has also been carried out using non-pressurized systems, and at a temperature of $100{ }^{\circ} \mathrm{C}[32,60,73]$. For aqueous pretreatment systems, the conditions have varied from $4 \%$ sulfuric acid to $0.5 \mathrm{~N}$ sodium hydroxide, from 80 to $200{ }^{\circ} \mathrm{C}$, and from 3 to $1440 \mathrm{~min}$ (Table 2). Thus, the lower temperature range used for analytical enzymatic saccharification differs considerably compared to what is commonly used for preparative experiments and the time periods are sometimes much longer than for normal pretreatment (Table 1). These differences can have a strong impact on the efficiency of the pretreatment, especially with regard to solubilization and hydrolysis of hemicelluloses.

The approaches differ with regard to potential separation of the solid and liquid phases after pretreatment (Figure 1, Table 2). In some studies, the solids have been collected by centrifugation and thoroughly washed and neutralized with water and buffer $[43,47,48,54-60,71,73]$, while in other studies there has only been a neutralization step using concentrated buffer to adjust the $\mathrm{pH}$ prior to the enzymatic digestion step (Table 2). Separation and washing is laborious, but the advantage is that more detailed information can be gathered from the experiment. If the solids are separated and washed, the subsequent enzymatic digestion becomes a direct measurement of the susceptibility of the pretreated lignocellulose to the enzymatic digestion. Furthermore, it becomes possible to distinguish between sugars formed during the pretreatment and during the enzymatic saccharification. If there is no separation of the liquid and solid phases, the ionic strength will become higher through $\mathrm{pH}$ adjustment using strong buffer, substances that inhibit enzymes and microorganisms are still left with the pretreated material and can affect subsequent biocatalytic reactions, and the sugar analysis will give the combined value for sugar formed during pretreatment and during enzymatic saccharification. 
Table 2. Examples of studies involving analytical-scale enzymatic saccharification ${ }^{\mathrm{a}, \mathrm{b}}$.

\begin{tabular}{|c|c|c|c|c|c|c|c|}
\hline Approach & $\begin{array}{l}\text { Feedstock; Particle Size; } \\
\text { Loading (DW) }\end{array}$ & Pretreatment Conditions & $\begin{array}{l}\text { Solid-Liquid Separation; } \\
\text { Wash }\end{array}$ & $\begin{array}{l}\text { Enzymatic Saccharification } \\
\text { (ES) }\end{array}$ & Analysis Methods & Sugar Yield (Control) & Ref. \\
\hline $\begin{array}{l}\text { Preparative PT (organosolv) } \\
\text { and analytical-scale ES (MTP) }\end{array}$ & $\begin{array}{c}\text { Yellow poplar wood; } 1.76 \mathrm{~g} \\
\text { wood chips per hand sheet } \\
\text { (PT); } 1.78 \mathrm{mg} \text { disk per } \\
\text { well (ES) }\end{array}$ & $\begin{array}{l}\text { Ethanol-Organosolv at } \\
195^{\circ} \mathrm{C} \text { for } \sim 90^{\circ}\end{array}$ & $\begin{array}{l}\text { Yes; Washes with ethanol } \\
\text { (70\%) and } \mathrm{H}_{2} \mathrm{O}\end{array}$ & $\begin{array}{c}\text { Desalted A and E separately; } \\
0.1 \mathrm{M} \mathrm{AB}(\mathrm{WC}) ; \mathrm{pH} 5.0 ; 500^{\circ} \mathrm{C} \\
24 \mathrm{~h} ; 600 \mathrm{rpm}\end{array}$ & $\begin{array}{l}\text { Glu (ES)-HPLC-PAD, enzyme } \\
\text { coupled assay (GOX-PRX). }\end{array}$ & $82 \%$ Cel $\Leftrightarrow$ Glu in $24 \mathrm{~h}$. & [65] \\
\hline $\begin{array}{l}\text { With and w/o preparative PT } \\
\text { (AFEX). Analytical-scale } \\
\text { ES (MWP) }\end{array}$ & $\begin{array}{c}\text { Corn stover; }<0.1 \mathrm{~mm} ; 1 \mathrm{~kg} \\
\text { BM (PT); } 1000 \mu 1 \text { PT slurry } \\
(0.25-1 \% \text { G load, ES) }\end{array}$ & $\begin{array}{c}\mathrm{AFEX}\left(1 \mathrm{~kg} \mathrm{NH}_{3}\right) \text { at } 90^{\circ} \mathrm{C} \\
\text { for } 5^{\prime} \text { (instantaneous } \\
\text { pressure release) }\end{array}$ & $\begin{array}{l}\mathrm{No} \text {; dried overnight to } \\
\text { remove } \mathrm{NH}_{3}\end{array}$ & $\begin{array}{c}\mathrm{C} \text { and B; } 0.05 \mathrm{M} \mathrm{CB}(\mathrm{WC}) ; \mathrm{pH} \\
4.8 ; 50^{\circ} \mathrm{C} ; 24 \mathrm{~h} ; 375 \mathrm{rpm}\end{array}$ & $\begin{array}{c}\text { Glu-HPLC-RID, } \\
\text { spectrophotometric assay } \\
\text { (Glu bio-enzymatic assay kit) }\end{array}$ & $\begin{aligned} 20 \% \mathrm{G} & \Leftrightarrow \mathrm{Glu}(\mathrm{ES} \text { w } / o \mathrm{PT}) \\
90 \% \mathrm{G} & \Leftrightarrow \mathrm{Glu}(\mathrm{PT}+\mathrm{ES})\end{aligned}$ & [69] \\
\hline $\begin{array}{l}\text { Combined PT and ES + ES } \\
\text { w/o PT (HTDP method). } \\
\text { HPT with acid or PT with } \\
\text { alkali in micronic tubes. }\end{array}$ & $\begin{array}{l}\text { Corn stover, A. thaliana; } \\
<0.35 \mathrm{~mm} \text { (robotic); } 1.5 \mathrm{mg} \\
\text { powder per micronic tube }\end{array}$ & $\begin{array}{l}\text { PT with alkali }(6.25 \text { or } \\
62.5 \mathrm{mM} \mathrm{NaOH} \text { ) at } 90^{\circ} \mathrm{C} \\
\text { for } 180^{\prime} \text {, or } \mathrm{HPT} \text { with } 2 \% \\
\mathrm{H}_{2} \mathrm{SO}_{4} \text { at } 120^{\circ} \mathrm{C} \text { for } 45^{\prime}\end{array}$ & $\begin{array}{c}\text { No; Neutralized with } \\
0.03 \mathrm{M} \mathrm{CB}, \mathrm{HCl} \text {, or } \mathrm{NaOH}\end{array}$ & $\begin{array}{c}\text { G; } 0.03 \mathrm{M} \mathrm{CB}(\mathrm{WC}) ; \mathrm{pH} 4.5 ; \\
50^{\circ} \mathrm{C} ; 20 \mathrm{~h} ; \\
\text { end-over-end rotation }\end{array}$ & $\begin{array}{l}\text { Glu-GOX-PRX; Xyl-XDH; } \\
\text { Total Mono content-alditol } \\
\text { acetate/GC method. }\end{array}$ & $\begin{array}{l}\text { Up to } 1500 \mathrm{nmol}(0.27 \mathrm{mg}) \\
\mathrm{Glu} / \mathrm{mg} \mathrm{BM}\end{array}$ & [64] \\
\hline $\begin{array}{l}\text { Combined PT (HPT) and ES } \\
\text { in Hastelloy 96-well format }\end{array}$ & $\begin{array}{l}\text { Poplar (around } 755 \text { variants); } \\
\quad<1 \mathrm{~mm} ; 5 \mathrm{mg} \text { per well }\end{array}$ & $\mathrm{HPT}$ at $180^{\circ} \mathrm{C}$ for $40^{\circ}$ & $\begin{array}{c}\text { No; Neutralized with } 1 \mathrm{M} \\
\mathrm{CB}, \mathrm{pH} 5.0\end{array}$ & $\begin{array}{l}\mathrm{C} \text { and } \mathrm{B} ; 1 \mathrm{MCB}(\mathrm{NC}), \mathrm{pH} 5.0 \\
40^{\circ} \mathrm{C}, 72 \mathrm{~h} \text {, static incubation }\end{array}$ & $\begin{array}{l}\text { Glu-GOX-PRX; Xyl-XDH; } \\
\text { Mono-HPLC-RID }\end{array}$ & $\begin{array}{l}\text { TSY (Glu+Xyl): } \\
0.17-0.64 \mathrm{~g} / \mathrm{g} \text { BM }\end{array}$ & [70] \\
\hline $\begin{array}{c}\text { Combined HTP-PT (HPT) } \\
\text { and ES + ES w/o PT } \\
\text { (Hastelloy 96-well format) } \\
\end{array}$ & $\begin{array}{c}\text { P. trichocarpa ( } 47 \text { phenotypes); } \\
0.180-0.85 \mathrm{~mm} ; 2.6 \mathrm{mg} \\
<2 \% \text { solids }\end{array}$ & $\begin{array}{l}\mathrm{HPT}\left(180^{\circ} \mathrm{C} \text { for } 18^{\prime},\right. \\
\text { or } 160^{\circ} \mathrm{C} \text { for } 28^{\prime}, \\
\left.\text { or } 140^{\circ} \mathrm{C} \text { for } 464^{\prime}\right)\end{array}$ & $\begin{array}{l}\text { No; Neutralized with } 1 \mathrm{M} \\
\text { CB pH } 4.95\end{array}$ & $\begin{array}{c}\mathrm{C} \text { and F; } 1 \mathrm{M} \mathrm{CB}(\mathrm{NC}) ; \\
\mathrm{pH} 4.95 ; 50^{\circ} \mathrm{C} ; 72 \mathrm{~h} ; 150 \mathrm{rpm} .\end{array}$ & Mono-HPLC-RID & $\begin{array}{c}\text { TSY: } 0.437-0.68 \mathrm{~g} / \mathrm{g} \mathrm{BM} \\
(\mathrm{PT}+\mathrm{ES}) ; 0.05-0.40 \mathrm{~g} / \mathrm{g} \mathrm{BM} \\
\text { (ES w/o PT) }\end{array}$ & [51-53] \\
\hline $\begin{array}{l}\text { Combined PT (PT with acid } \\
\text { or alkali) and ES } \\
\text { ( } 96 \text { MWP format). }\end{array}$ & $\begin{array}{l}\text { A. thaliana, Brachypodium, } \\
\text { poplar, maize, barley, tobacco; } \\
\text { powder; } 4 \text { mg per well }\end{array}$ & $\begin{array}{l}\text { PT with } 0.5-4 \% \mathrm{H}_{2} \mathrm{SO}_{4} \text { or } \\
0.5 \mathrm{~N} \mathrm{NaOH}, 90^{\circ} \mathrm{C}, \\
\text { time variable depending } \\
\text { on plant material }\end{array}$ & Yes; $0.025 \mathrm{M} \mathrm{AB}$ wash & $\begin{array}{l}\text { Desalted } \mathrm{A} \text { and } \mathrm{B} ; 0.025 \mathrm{M} \\
\mathrm{AB} ; \mathrm{pH} 4.5 ; 50^{\circ} \mathrm{C} \text {; shaking }\end{array}$ & $\begin{array}{l}\text { RS-MTBH assay; Mono } \\
\text { (PTL and ES)-HPAEC-ECD }\end{array}$ & $\begin{array}{c}\text { Tobacco WT: } 50 \text { umol }(9 \mathrm{mg}) \\
\text { Glu/g BM }\end{array}$ & {$[62,63]$} \\
\hline Combined PT (HPT) and ES & $\begin{array}{l}\text { A. mangium (transgenic); } \\
\text { powder; } 100 \mathrm{mg}\end{array}$ & HPT at $120^{\circ} \mathrm{C}$ for $3^{\prime}$ & Yes; $\mathrm{H}_{2} \mathrm{O}$ wash & $\begin{array}{c}\mathrm{H} ; 0.05 \mathrm{M} \mathrm{AB} ; \mathrm{pH} 4.8 ; 0.02 \% \\
\text { Tween-20; } 45^{\circ} \mathrm{C} ; 48 \mathrm{~h} \\
135 \mathrm{rpm}\end{array}$ & $\begin{array}{l}\text { RS (ES)-Somogyi- } \\
\text { Nelson method; Glu } \\
\text { (ES)-GOX method }\end{array}$ & $\begin{array}{l}9.4 \mathrm{mg} \mathrm{RS} / 100 \mathrm{mg} \text { BM, } \\
6.8 \mathrm{Glu} \mathrm{mg} / 100 \mathrm{mg} \text {. }\end{array}$ & [61] \\
\hline $\begin{array}{l}\text { Combined PT (HPT with acid } \\
\text { using ASE 350) and ES. }\end{array}$ & $\begin{array}{l}156 \text { different feedstocks: } \\
\text { corn stover, poplar, etc.; } \\
\quad<2 \mathrm{~mm} ; 3 \mathrm{~g}\end{array}$ & $\begin{array}{l}\text { HPT with } 1 \% \mathrm{H}_{2} \mathrm{SO}_{4} \text { at } \\
110-200^{\circ} \mathrm{C} \text { for 13' } \\
\left(7^{\prime} \text { heating, } 6^{\prime} \text { static) }\right.\end{array}$ & Yes; $\mathrm{H}_{2} \mathrm{O}$ wash & $\begin{array}{c}\mathrm{D} ; 0.1 \mathrm{M} \mathrm{CB} ; \mathrm{pH} 4.8 ; 48 \mathrm{~h} ; \\
\text { 5-7 days }\end{array}$ & $\begin{array}{l}\text { Glu and Xyl (PTL and } \\
\text { ES)-HPLC-RID }\end{array}$ & $\begin{array}{l}\text { Corn stover: } \mathrm{PT}+\mathrm{ES} 0.309 \mathrm{~g} \\
\text { Glu and } 0.228 \mathrm{~g} \mathrm{Xyl} / \mathrm{g} \text { BM. }\end{array}$ & [68] \\
\hline $\begin{array}{l}\text { Combined PT (HPT with } \\
\text { alkali using Hastelloy 96-well } \\
\text { format) and ES. }\end{array}$ & $\begin{array}{l}\text { Switchgrass, } \text { P. tremuloides; } \\
0.180-0.85 \mathrm{~mm} ; 4.5 \mathrm{mg}\end{array}$ & $\begin{array}{l}\text { HPT with } 1 \% \mathrm{NaOH} \text { at } \\
120^{\circ} \mathrm{C} \text { for } 10-1440^{\prime}\end{array}$ & $\begin{array}{c}\text { No; diluted with } \mathrm{H}_{2} \mathrm{O}, \\
\text { neutralized with } 1 \mathrm{M} \text { CB, } \\
\text { pH 4.5 }\end{array}$ & $\begin{array}{l}\mathrm{C} \text { and F; } 1 \mathrm{M} \mathrm{CB}(\mathrm{NC}) ; \mathrm{pH} \\
4.95 ; 50^{\circ} \mathrm{C} ; 72 \mathrm{~h} ; 150 \mathrm{rpm} .\end{array}$ & Mono-HPLC-RID & $\begin{array}{l}\text { Poplar: 49-69\% (Glu+Xyl); } \\
\text { Switch-grass: } 85 \% \text { (Glu) }\end{array}$ & [72] \\
\hline $\begin{array}{l}\text { Combined PT (PT with acid) } \\
\text { and ES + ES w/o PT }\end{array}$ & $\begin{array}{c}\text { P. tremula } \times \text { P. alba } \\
\text { (green house); powder; } 10 \mathrm{mg}\end{array}$ & $\begin{array}{l}\text { PT with } 1 \mathrm{ml} \text { of } 1 \mathrm{~N} \mathrm{HCl} \\
\text { at } 80^{\circ} \mathrm{C} \text { for } 120^{\prime}\end{array}$ & $\begin{array}{l}\text { Yes; } \mathrm{H}_{2} \mathrm{O} \text { wash, } 70 \%(v / v) \\
\text { ethanol, and } 100 \% \text { acetone }\end{array}$ & $\begin{array}{c}\text { Desalted } \mathrm{A} \text { and } \mathrm{B} ; \mathrm{AB} \text { pH } 4.8 \\
50^{\circ} \mathrm{C} ; 48 \mathrm{~h}\end{array}$ & $\begin{array}{l}\text { Glu in ES (with and w/o } \\
\text { PT)-GOX-PRX assay }\end{array}$ & $16-18 \%$ Cel $\Leftrightarrow$ Glu & [66] \\
\hline $\begin{array}{l}\text { HTDP: combined PT (HPT } \\
\text { with acid or PT with alkali) } \\
\text { and ES }\end{array}$ & $\begin{array}{c}\text { P. tremula } \times \text { P. alba } \\
\text { (field grown); powder; } 1.5 \mathrm{mg}\end{array}$ & $\begin{array}{c}\text { HPT with } 0.4 \mathrm{M} \mathrm{H}_{2} \mathrm{SO}_{4} \\
\left(120^{\circ} \mathrm{C}, 45^{\prime}\right) \text {, or PT with } \\
6.25 \text { or } 62.5 \mathrm{mM} \mathrm{NaOH} \\
\left(90^{\circ} \mathrm{C}, 180^{\prime}\right)\end{array}$ & $\begin{array}{l}\text { No; Neutralized with acid } \\
\text { or base depending on PT. }\end{array}$ & $\begin{array}{l}\text { Desalted A and B; } \mathrm{AB} \text { pH } 4.8 ; \\
50^{\circ} \mathrm{C} ; 48 \mathrm{~h}\end{array}$ & HPLC-RID & $16-69 \% \mathrm{Cel} \Leftrightarrow \mathrm{Glu}$ & [67] \\
\hline
\end{tabular}


Table 2. Cont.

\begin{tabular}{|c|c|c|c|c|c|c|c|}
\hline Approach & $\begin{array}{l}\text { Feedstock; Particle Size; } \\
\text { Loading (DW) }\end{array}$ & Pretreatment Conditions & $\begin{array}{l}\text { Solid-Liquid Separation; } \\
\text { Wash }\end{array}$ & $\begin{array}{l}\text { Enzymatic Saccharification } \\
\text { (ES) }\end{array}$ & Analysis Methods & Sugar Yield (Control) & Ref. \\
\hline $\begin{array}{l}\text { Combined PT (HPT with acid } \\
\text { using robotic single-mode } \\
\text { microwave system) and } \\
\text { ES + ES w/o PT. }\end{array}$ & $\begin{array}{l}\text { Hybrid aspen; } 0.1-0.5 \mathrm{~mm} ; \\
50 \mathrm{mg}\end{array}$ & $\begin{array}{l}\text { HPT with } 1 \% \mathrm{H}_{2} \mathrm{SO}_{4} \text { at } \\
165^{\circ} \mathrm{C} \text { for } 10^{\prime}\end{array}$ & $\begin{array}{l}\text { Yes; } \mathrm{H}_{2} \mathrm{O} \text { wash and } \\
0.05 \mathrm{M} \mathrm{CB}(\mathrm{pH} 5.2) \text {. }\end{array}$ & $\begin{array}{c}\mathrm{A} \text { and } \mathrm{B} ; 0.05 \mathrm{M} \mathrm{CB} \mathrm{pH} 5.2 ; 45 \\
{ }^{\circ} \mathrm{C} ; 72 \mathrm{~h} ; 170 \mathrm{rpm}\end{array}$ & $\begin{array}{c}\text { Mono (PTL and } \\
\text { ES)-HPAEC-ECD; } \\
\text { Glu (ES)-GOX; ACA } \\
\text { (PTL)-HPAEC-CD }\end{array}$ & $\begin{array}{c}\text { Glu (g/g BM): } 0.1-0.25 \mathrm{~g}(\mathrm{ES}) ; \\
0.35-0.5 \mathrm{~g}(\mathrm{PT}+\mathrm{ES})\end{array}$ & {$[47,48,54-58,71]$} \\
\hline $\begin{array}{l}\text { Combined PT (HTP with acid } \\
\text { using robotic single-mode } \\
\text { micro-wave system) and } \\
\text { ES + ES w/o PT. }\end{array}$ & $\begin{array}{l}\text { Scots pine, Norway spruce; } \\
0.1-0.5 \mathrm{~mm} ; 50 \mathrm{mg}\end{array}$ & $\begin{array}{l}\text { HPT with } 2-4 \% \mathrm{H}_{2} \mathrm{SO}_{4} \text { at } \\
180^{\circ} \mathrm{C} \text { for } 5-30^{\prime}\end{array}$ & $\begin{array}{l}\text { Yes; } \mathrm{H}_{2} \mathrm{O} \text { wash and } \\
0.05 \mathrm{M} \mathrm{CB} \text { (pH 5.2). }\end{array}$ & $\begin{array}{l}\text { A and B; } 0.05 \mathrm{M} \mathrm{CB} \text {; pH 5.2; } \\
45^{\circ} \mathrm{C} ; 72 \mathrm{~h} ; 170 \mathrm{rpm}\end{array}$ & $\begin{array}{l}\text { Mono (PTL and } \\
\text { ES)-HPAEC-ECD; } \\
\text { Glu (ES)-GOX; ACA } \\
\text { (PTL)-HPAEC-CD }\end{array}$ & $\begin{array}{l}\text { Glu (g/g BM): } 0.03-0.10 \mathrm{~g} \\
\text { (ES); 0.1-0.34 g (PT+ES) }\end{array}$ & {$[59,60]$} \\
\hline $\begin{array}{l}\text { Combined IL-PT and } \\
\text { ES + ES w/o PT }\end{array}$ & $\begin{array}{l}\text { Hybrid aspen, Norway } \\
\text { spruce; } 0.1-0.5 \mathrm{~mm} ; 50 \mathrm{mg}\end{array}$ & $\begin{array}{c}950 \mathrm{mg} \mathrm{IL}([\mathrm{Bmim}] \\
{\left[\mathrm{HSO}_{4}\right],[\mathrm{Bmim}][\mathrm{Ac}]} \\
{[\mathrm{Bmim}][\mathrm{Cl}], \text { or }} \\
{\left[\text { Amim][Ac]) at } 100^{\circ} \mathrm{C}\right.} \\
\text { for } 1200^{\prime}\end{array}$ & $\begin{array}{l}\text { Yes; } \mathrm{H}_{2} \mathrm{O} \text { wash and } 0.05 \\
\text { M CB (pH 5.2). }\end{array}$ & $\begin{array}{l}\text { A and B; } 0.05 \mathrm{M} \mathrm{CB} ; \mathrm{pH} 5.2 ; \\
45^{\circ} \mathrm{C} ; 72 \mathrm{~h} ; 170 \mathrm{rpm}\end{array}$ & $\begin{array}{c}\text { Mono (PTL and } \\
\text { ES)-HPAEC-ECD; Glu-GOX; } \\
\text { ACA (PTL)-HPLC-RID; } \\
\text { furans (PTL)-HPLC-DAD. }\end{array}$ & $\begin{array}{c}\text { Glu (g/g BM): aspen, } 0.1 \mathrm{~g} \\
\text { (ES), } 0.13-0.35 \mathrm{~g}(\mathrm{PT}+\mathrm{ES}) ; \\
\text { spruce, } 0.03 \mathrm{~g}(\mathrm{ES}), 0.4 \mathrm{~g} \\
\text { (PT+ES) }\end{array}$ & {$[43,60,73]$} \\
\hline $\begin{array}{l}\text { PT (HPT) and ES + ES w/o } \\
\text { PT (Hastelloy 96-well format) }\end{array}$ & $\begin{array}{l}\text { P. deltoides, Switch grass, Rice; } \\
0.85-1 \mathrm{~mm} ; 5 \mathrm{mg}\end{array}$ & HPT at $180^{\circ} \mathrm{C}$ for $17.5^{\prime}$ & No. & $\begin{array}{c}\mathrm{D} ; 1.0 \mathrm{MCB}(\mathrm{NC}) ; \mathrm{pH} 5.0 ; \\
50^{\circ} \mathrm{C} ; 70 \text { h; static incubation }\end{array}$ & Glu-GOX-PRX; Xyl-XDH & $\begin{array}{c}\text { Poplar: }(0.32 \mathrm{~g} \mathrm{Glu} \text { and } 0.17 \mathrm{~g} \\
\text { Xyl) / g BM }\end{array}$ & {$[49,50,53]$} \\
\hline \multicolumn{8}{|c|}{$\begin{array}{l}\text { a AB, acetate buffer; ACA, aliphatic carboxylic acids; BM, biomass; Cel, cellulose; CD: conductivity detector; CB, citrate buffer; DAD, Diode array detector; DW, dry weight; ECD, } \\
\text { electrochemical detector; ES, enzymatic saccharification; G, glucan; Glu, glucose; GOX, assay based on glucose oxidase; GOX-PRX, assay based on glucose oxidase and peroxidase; } \\
\text { HPT, hydrothermal pretreatment; HTP, high throughput; HTDP, High-throughput digestibility platform; HPAEC, high-performance anion-exchange chromatography; IL, ionic liquid; } \\
\text { Mono, monosaccharides; MTP, microtiter plate; MTBH, 3-methyl-2-benzothiazolinone hydrozone; MWP, microwell plates; NC: concentration used for neutralization; PAD, pulsed } \\
\text { amperometric detector; PT, pretreatment; PTL, pretreament liquid; RID, refractive index detector; RS, reducing sugar; TSY, Total sugar yields; XDH, assay based on xylose dehydrogenase; } \\
\text { Xyl, xylose; WC: working concentration; without, w/o. b Enzyme preparations (supplier/manufacturer): A, Celluclast 1.5L from T. reesei ATCC } 26921 \text { (Sigma-Aldrich, St. Louis, MO, USA); } \\
\text { B, Novozym } 188 \text { from A. niger (Sigma-Aldrich); C, Spezyme CP (Genencor International, Rochester, NY); D, Cellic CTec2 (Sigma-Aldrich); E, Cellulase from Penicillium sp (MSUBC1) } \\
\text { (laboratory preparation); F, Multifect xylanase (Genencor); G, Accellerase } 1000 \text { (Genencor); H, Cellulase preparation from Trichoderma viridae (Meicelase; Meiji Seika, Tokyo, Japan). }\end{array}$} \\
\hline
\end{tabular}


The next step will be the enzymatic saccharification. Most analytical-scale approaches have relied on commercially available cellulase preparations, such as Celluclast $1.5 \mathrm{~L}$ (from T. reesei ATCC 26921) (supplied by Sigma-Aldrich, St. Louis, MO, USA), Spezyme CP (from T. reesei) (Genencor International, Rochester, NY, USA), Accelerase 1000 (from T. reesei) (Genencor), and Cellic CTec2 (Sigma-Aldrich), $\beta$-glucosidase preparations, such as Novozym 188 (from A. niger) (Sigma-Aldrich), and hemicellulase preparations, such as Multifect xylanase (from T. reesei) (Genencor). As further detailed in Table 2, a combination of two or sometimes three of the aforementioned enzyme preparations have often been used to assure efficient degradation of the lignocellulosic biomass. In some enzymatic saccharification assays, the enzyme preparations were desalted prior to use to remove low-molecular-weight substances, especially sugars that could otherwise cause feedback inhibition of enzymes $[62,63,65]$. As mentioned above, a separation step or at least a neutralization step to reach a suitable $\mathrm{pH}$ for the enzymatic reaction is typically included. If not, very high enzyme loadings may be required to counteract suboptimal conditions during the enzymatic digestion step [51,52]. Some studies have included attempts to follow the reaction rate at different phases of cellulose saccharification by taking multiple samples rather than focusing only on end-point values. These studies have included sampling after 1, 2, 3, 6, 12, 24, 48, and $72 \mathrm{~h}[65,69]$, or sampling at an early time point ( 2 or $4 \mathrm{~h}$ ) and then at the end of the reaction $(72 \mathrm{~h})$ [21,57-60]. The sugar yield from the different approaches listed in Table 2 ranges from as low as $9 \mathrm{mg}$ of reducing sugar per gram biomass [62,63] to as high as $0.5 \mathrm{~g}$ of glucose per gram biomass [48]. These yields depend on several factors, such as type of feedstock, particle size, pretreatment severity, and conditions for enzymatic saccharification.

\subsection{Analysis of Reaction Mixtures}

After the enzymatic reaction, or possibly after the fermentation step if that is included in the procedure, the liquid samples generated after pretreatment, enzymatic saccharification, combined pretreatment and enzymatic saccharification, and/or fermentation are analyzed using one or several analytical methods (Figure 1). The analytical methods that are used vary from simple spectrophotometric methods (for reducing sugars, and most enzyme-based assays) to more sophisticated methods, such as high-performance liquid or anion-exchange chromatography (HPLC and HPAEC), mass spectrometry (MS), and capillary electrophoresis (CE) (Figure 1). As indicated in Table 2, monosaccharide sugars (typically arabinose, galactose, glucose, xylose, and mannose), aliphatic acids (acetic acid, formic acid, and levulinic acid), and furan aldehydes (furfural and 5-hydroxymethyl furfural) are the most common analytes. Most HTP procedures rely on spectrophotometric enzyme-linked analysis methods (Table 2), as they are simpler to automate. However, they provide less detailed information than the more sophisticated methods.

Spectrophotometric assays can be chemical based or enzyme based. Chemical-based assays for determination of reducing sugar include the dinitrosalicylic acid (DNS) [75,76], the Nelson-Somogyi [77], the bicinchoninic acid (BCA) [78], and the 3-methyl-2-benzothiazolinonehydrazone (MBTH) methods [79]. The DNS method, especially, is widely used for this purpose. The carbonyl group at the reducing end of the sugars reduces 3,5-dinitrosalicylic acid to 3-amino-5-nitrosalicylic acid with a concomitant increase in absorbance at $540 \mathrm{~nm}$. The DNS assay has low sensitivity and requires alkaline $\mathrm{pH}$ and temperatures around $100{ }^{\circ} \mathrm{C}$ for color development. The BCA method $(562 \mathrm{~nm})$ and the Nelson-Somogyi method $(660 \mathrm{~nm})$, which are more sensitive than the DNS assay, are based on the reduction of cupric ions to cuprous ions by the reducing groups of the sugars. The main drawback of these methods is the interference of protein with the reaction. The MBTH method $(620 \mathrm{~nm})$, which is also more sensitive than the DNS method, can be carried out under acidic conditions. Due to the higher sensitivity, lower concentration samples can be used for the analysis. The main disadvantage is interference of oligomeric sugars from the PTL (pretreatment liquid) and the enzymatic hydrolysate, especially if the $\beta$-glucosidase and 
xylosidase activities are low. Gomez et al. downscaled this assay for use in a 96-well format HTP platform $[62,63]$.

The enzyme-based assays, which are also based on redox reactions, are more sensitive than the reducing sugar assays, as they are specific for the target sugar detected. Glucose is analyzed by using (i) glucose oxidase (GOX), (ii) the coupled glucose oxidase and peroxidase method (GOX-PRX) [80], and (iii) the hexokinase and glucose-6-phosphate dehydrogenase method or glucose bio-enzymatic method [81]. Many researchers have used the GOX-based glucometer-strip method as an initial check point for the release of glucose in the enzymatic reaction mixture (Table 2). This is a quick and simple method for estimating glucose concentrations. In the GOX-PRX assay, GOX oxidizes glucose to gluconic acid while peroxidase oxidizes $\mathrm{O}$-dianisidine. The reaction is stopped by adding hydrochloric or sulfuric acid, and the formation of red color is monitored at $510 \mathrm{~nm}$. The glucose- 6 phosphate dehydrogenase $(\mathrm{GDH})$ and xylose dehydrogenase $(\mathrm{XDH})$ methods are coupled assays that are typically performed at room temperature for 5-30 min. $\mathrm{NAD}^{+}$(nicotinamide adenine dinucleotide, oxidized form) is reduced to NADH (nicotinamide adenine dinucleotide, reduced form), which is monitored at $340 \mathrm{~nm}$. Although these enzyme-linked assays are widely used in HTP platforms, disadvantages include that they are typically more expensive than assays based only on chemicals, that the enzymes are sensitive to deactivation by inhibitors in the PTL, and that they are sensitive to interference caused by oligomeric sugar. In addition to the above-mentioned widely used assays, some researchers have also used immobilized enzymes to analyze glucose and xylose [82-85].

Analyses of reaction mixtures using sophisticated instrumental analysis are more sensitive and precise and can be used for analysis of multiple sugars, aliphatic acids, and furan aldehydes. Chromatographic separation methods, such as HPLC and HPAEC, combined with refractometric, pulsed amperometric, electrochemical, and conductivity detection have been widely used by many researchers to analyze monosaccharides, such as glucose, xylose, galactose, arabinose, and mannose, disaccharides, such as cellobiose, aliphatic acids, such as acetic acid, formic acid, and levulinic acid, and furan aldehydes, such as furfural and 5-hydroxymethyl furfural (Table 2). In addition, tandem mass spectrometry (MS-MS) [86], gas chromatography-mass spectrometry (GC-MS), and capillary electrophoresis (CE) [87] with electrochemical detection have also been used. The main drawbacks of these methods, at least with regard to the HTP format, is the requirement of sample preparation by filtration and sometimes neutralization and derivatization, and the long retention times, which typically amount to more than 20 min per sample. In addition, purchase of instruments, columns, and detectors, and operational costs, such as consumables (carrier gas, sample vials, filters, solvents, standards, and derivatization reagents) and maintenance, contribute to making these methods expensive. Nevertheless, due to that these methods offer high precision and accuracy and are less prone to interference by inhibitors, they have been widely used in analytical-scale saccharification studies.

\section{Conclusions}

As a result of increased efforts to commercialize bioconversion of lignocellulosic feedstocks to advanced biofuels, semi-automated or HTP-based assessment of the susceptibility of the feedstocks to pretreatment and enzymatic saccharification have undergone a rapid development during the past decade. This technology development has occurred concomitantly with the first attempts to launch cellulose-to-ethanol processes on a commercial scale. Several different approaches to analytical enzymatic saccharification have been developed. Some of these have emphasis on HTP screening of large numbers of samples, whereas others have emphasis on industrial-like pretreatment conditions and detailed analysis of reaction mixtures. Analytical enzymatic saccharification has proved to be especially useful for achieving a better understanding of the factors behind the recalcitrance of lignocellulosic feedstocks, a key issue for continued progress in making production of advanced biofuels more efficient and cost competitive. 
Author Contributions: All authors contributed to the design of the study, the literature review, and the writing of the paper.

Funding: This research was funded by the Swedish Energy Agency (P41285-1, P43974-1) and the strategic research environment Bio4Energy.

Conflicts of Interest: The authors declare no conflict of interest.

\section{References}

1. Tracking Clean Energy Progress 2017; International Energy Agency: Paris, France, 2017.

2. Chum, H.L.; Warner, E.; Seabra, J.E.A.; Macedo, I.C. A comparison of commercial ethanol production systems from Brazilian sugarcane and US corn. Biofuels Bioprod. Bioref. 2014, 8, 205-223. [CrossRef]

3. Manochio, C.; Andrade, B.R.; Rodriguez, R.P.; Moraes, B.S. Ethanol from biomass: A comparative overview. Renew. Sust. Energ. Rev. 2017, 80, 743-755. [CrossRef]

4. Alternative Fuels Data Center. Available online: https://www.afdc.energy.gov/data/ (accessed on 22 October 2018).

5. Chollacoop, N.; Saisirirat, P.; Fukuda, T.; Fukuda, A. Scenario analyses of road transport energy demand: A case study of ethanol as a diesel substitute in Thailand. Energies 2011, 4, 108-125. [CrossRef]

6. Geleynse, S.; Brandt, K.; Garcia-Perez, M.; Wolcott, M.; Zhang, X. The alcohol-to-jet conversion pathway for drop-in biofuels: Techno-economic evaluation. ChemSusChem 2018. [CrossRef] [PubMed]

7. Sanderson, K. Lignocellulose: A chewy problem. Nature 2011, 474, S12-S14. [CrossRef] [PubMed]

8. Meng, X.; Ragauskas, A.J. Recent advances in understanding the role of cellulose accessibility in enzymatic hydrolysis of lignocellulosic substrates. Curr. Opin. Biotechnol. 2014, 27, 150-158. [CrossRef] [PubMed]

9. Den Haan, R.; Kroukamp, H.; Mert, M.; Bloom, M.; Görgens, J.F.; van Zyl, W.H. Engineering Saccharomyces cerevisiae for next generation ethanol production. J. Chem. Technol. Biotechnol. 2013, 88, 983-991. [CrossRef]

10. Arantes, V.; Saddler, J.N. Cellulose accessibility limits the effectiveness of minimum cellulase loading on the efficient hydrolysis of pretreated lignocellulosic substrates. Biotechnol. Biofuels 2011, 4, 3. [CrossRef] [PubMed]

11. Donev, E.; Gandla, M.L.; Jönsson, L.J.; Mellerowicz, E. Engineering non-cellulosic polysaccharides of wood for the biorefinery. Front. Plant Sci. 2018, 9, 1537. [CrossRef]

12. Fengel, D.; Wegener, G. Wood-Chemistry, Ultrastructure, Reactions; Walter de Gruyter: Berlin, Germany, 1989.

13. Ragauskas, A.J. Materials for Biofuels; World Scientific: Singapore, 2014.

14. Ciolacu, D.; Ciolacu, F.; Popa, V.I. Amorphous cellulose-structure and characterization. Cellulose Chem. Technol. 2011, 45, 13-21.

15. Xiao, B.; Sun, X.F.; Sun, R.C. Chemical, structural, and thermal characterizations of alkali-soluble lignins and hemicelluloses, and cellulose from maize stems, rye straw, and rice straw. Polym. Degrad. Stabil. 2001, 74, 307-319. [CrossRef]

16. Chundawat, S.P.S.; Beckham, G.; Himmel, M.E.; Dale, B.E. Deconstruction of lignocellulosic biomass to fuels and chemicals. Annu. Rev. Chem. Biomol. Eng. 2011, 2, 121-145. [CrossRef] [PubMed]

17. Zhao, X.B.; Zhang, L.H.; Liu, D.H. Biomass recalcitrance. Part I: The chemical compositions and physical structures affecting the enzymatic hydrolysis of lignocellulose. Biofuels Bioprod. Bioref. 2012, 6, 465-482. [CrossRef]

18. Herbaut, M.; Zoghlami, A.; Habrant, A.; Falourd, X.; Foucat, L.; Chabbert, B.; Paës, G. Multimodal analysis of pretreated biomass species highlights generic markers of lignocellulose recalcitrance. Biotechnol. Biofuels 2018, 11, 52. [CrossRef] [PubMed]

19. Wang, Z.; Jönsson, L.J. Comparison of catalytically non-productive adsorption of fungal proteins to lignins and pseudo-lignin using isobaric mass tagging. Bioresour. Technol. 2018, 268, 393-401. [CrossRef] [PubMed]

20. Kumar, R.; Bhagia, S.; Smith, M.D.; Petridis, L.; Ong, R.G.; Cai, C.M.; Mittal, A.; Himmel, M.H.; Balan, V.; Dale, B.E.; et al. Cellulose-hemicellulose interactions at elevated temperatures increase cellulose recalcitrance to biological conversion. Green Chem. 2018, 20, 921-934. [CrossRef]

21. Wang, Z.; Winestrand, S.; Gillgren, T.; Jönsson, L.J. Chemical and structural factors influencing enzymatic saccharification of wood from aspen, birch and spruce. Biomass Bioenergy 2018, 109, 125-134. [CrossRef] 
22. Jönsson, L.J.; Martín, C. Pretreatment of lignocellulose: Formation of inhibitory by-products and strategies for minimizing their effects. Bioresour. Technol. 2016, 199, 103-112. [CrossRef] [PubMed]

23. Zhao, X.B.; Zhang, L.H.; Liu, D.H. Biomass recalcitrance. Part II: Fundamentals of different pre-treatments to increase the enzymatic digestibility of lignocellulose. Biofuels Bioprod. Bioref. 2012, 6, 561-579. [CrossRef]

24. Mosier, N.; Wyman, C.; Dale, B.; Elander, R.; Lee, Y.Y.; Holtzapple, M.; Ladisch, M. Features of promising technologies for pretreatment of lignocellulosic biomass. Bioresour. Technol. 2005, 96, 673-686. [CrossRef] [PubMed]

25. Ruiz, H.A.; Rodríguez-Jasso, R.M.; Fernandes, B.D.; Vicente, A.A.; Teixeira, J.A. Hydrothermal processing, as an alternative for upgrading agriculture residues and marine biomass according to the biorefinery concept: A review. Renew. Sust. Energ. Rev. 2013, 21, 35-51. [CrossRef]

26. Bhagia, S.; Kumar, R.; Wyman, C.E. Effects of dilute acid and flowthrough pretreatments and BSA supplementation on enzymatic deconstruction of poplar by cellulase and xylanase. Carbohydr. Polym. 2017, 157, 1940-1948. [CrossRef] [PubMed]

27. Silveira, M.H.L.; Morais, A.R.C.; Lopes, A.M.C.; Olekszyszen, D.N.; Bogel-Łukasik, R.; Andreaus, J.; Ramos, L.P. Current pretreatment technologies for the development of cellulosic ethanol and biorefineries. ChemSusChem 2015, 8, 3366-3390. [CrossRef] [PubMed]

28. Kim, J.S.; Lee, Y.Y.; Kim, T.H. A review on alkaline pretreatment technology for bioconversion of lignocellulosic biomass. Bioresour. Technol. 2016, 199, 42-48. [CrossRef] [PubMed]

29. Balan, V.; Bals, B.; Chundawat, S.P.S.; Marshall, D.; Dale, B.E. Lignocellulosic biomass pretreatment using AFEX. Methods Mol. Biol. 2009, 581, 93-102.

30. Zhou, H.F.; Zhu, J.Y.; Gleisner, T.; Qiu, X.Q.; Horn, E.; Negrón, J. Pilot-scale demonstration of SPORL for bioconversion of lodgepole pine to bioethanol and lignosulfonate. Holzforschung 2016, 70, 21-30. [CrossRef]

31. Silva, A.R.G.; Errico, M.; Rong, B.G. Techno-economic analysis of organosolv pretreatment process from lignocellulosic biomass. Clean Techn. Environ. Policy 2018, 20, 1401-1412. [CrossRef]

32. Wang, Z.; Gräsvik, J.; Jönsson, L.J.; Winestrand, S. Comparison of $\left[\mathrm{HSO}_{4}\right]^{-},[\mathrm{Cl}]^{-}$and $\left[\mathrm{MeCO}_{2}\right]^{-}$as anions in the pretreatment of aspen and spruce with imidazolium-based ionic liquid. BMC Biotechnol. 2017, 17, 82. [CrossRef] [PubMed]

33. Karatzos, S.K.; Edye, L.A.; Doherty, W.O.S. Sugarcane bagasse pretreatment using three imidazolium-based ionic liquids; mass balances and enzyme kinetics. Biotechnol. Biofuels 2012, 5, 62. [CrossRef] [PubMed]

34. Cao, Y.J.; Zhang, R.B.; Cheng, T.; Guo, J.; Xian, M.; Liu, H.Z. Imidazolium-based ionic liquids for cellulose pretreatment: Recent progresses and future perspectives. Appl. Microbiol. Biotechnol. 2017, 101, 521-532. [CrossRef] [PubMed]

35. Qu, T.J.; Zhang, X.M.; Gu, X.W.; Han, L.J.; Ji, G.Y.; Chen, X.L.; Xiao, W.H. Ball milling for biomass fractionation and pretreatment with aqueous hydroxide solutions. ACS Sustain. Chem. Eng. 2017, 5, 7733-7742. [CrossRef]

36. Vasco-Correa, J.; Ge, X.; Li, Y. Biological pretreatment of lignocellulosic biomass. In Biomass Fractionation Technologies for a Lignocellulosic Feedstock Based Biorefinery; Mussatto, S.I., Ed.; Elsevier: Amsterdam, The Netherlands, 2016; pp. 561-585. ISBN 978-0-12-802323-5.

37. Van Dyk, J.S.; Pletschke, B.I. A review of lignocellulose bioconversion using enzymatic hydrolysis and synergistic cooperation between enzymes - factors affecting enzymes, conversion and synergy. Biotechnol. Adv. 2012, 30, 1458-1480. [CrossRef] [PubMed]

38. Kubicek, C.P. Systems biological approaches towards understanding cellulase production by Trichoderma reesei. J. Biotechnol. 2013, 163, 133-142. [CrossRef] [PubMed]

39. Jun, H.; Kieselbach, T.; Jönsson, L.J. Enzyme production by filamentous fungi: Analysis of the secretome of Trichoderma reesei grown on unconventional carbon source. Microb. Cell. Fact. 2011, 10, 68. [CrossRef] [PubMed]

40. Adav, S.S.; Chao, L.T.; Sze, S.K. Quantitative secretomic analysis of Trichoderma reesei strains reveals enzymatic composition for lignocellulosic biomass degradation. Mol. Cell. Proteom. 2012, 11, M111-012419. [CrossRef] [PubMed]

41. Horn, S.J.; Vaaje-Kolstad, G.; Westereng, B.; Eijsink, V.G.H. Novel enzymes for the degradation of cellulose. Biotechnol. Biofuels 2012, 5, 45. [CrossRef] [PubMed]

42. Morgenstern, I.; Powlowski, J.; Tsang, A. Fungal cellulose degradation by oxidative enzymes: From dysfunctional GH61 family to powerful lytic polysaccharide monooxygenase family. Brief. Funct. Genom. 2014, 13, 471-481. [CrossRef] [PubMed] 
43. Wang, Z.; Wu, G.; Jönsson, L.J. Effects of impregnation of softwood with sulfuric acid and sulfur dioxide on chemical and physical characteristics, enzymatic digestibility, and fermentability. Bioresour. Technol. 2018, 247, 200-208. [CrossRef] [PubMed]

44. Pareek, N.; Gillgren, T.; Jönsson, L.J. Adsorption of proteins involved in hydrolysis of lignocellulose on lignins and hemicelluloses. Bioresour. Technol. 2013, 148, 70-77. [CrossRef] [PubMed]

45. Ooshima, H.; Sakata, M.; Harano, Y. Enhancement of enzymatic hydrolysis of cellulose by surfactant. Biotechnol. Bioeng. 1986, 28, 1727-1734. [CrossRef] [PubMed]

46. Jeoh, T.; Cardona, M.J.; Karuna, N.; Mudinoor, A.R.; Nill, J. Mechanistic kinetic models of enzymatic cellulose hydrolysis-A review. Biotechnol. Bioeng. 2017, 114, 1369-1385. [CrossRef] [PubMed]

47. Biswal, A.K.; Soeno, K.; Gandla, M.L.; Immerzeel, P.; Pattathil, S.; Lucenius, J.; Serimaa, R.; Hahn, M.G.; Moritz, T.; Jönsson, L.J.; et al. Aspen pectate lyase PtxtPL1-27 mobilizes matrix polysaccharides from woody tissues and improves saccharification yield. Biotechnol. Biofuels 2014, 7, 11. [CrossRef] [PubMed]

48. Gandla, M.L.; Derba-Maceluch, M.; Liu, X.; Gerber, L.; Master, E.R.; Mellerowicz, E.J.; Jönsson, L.J. Expression of a fungal glucuronoyl esterase in Populus: Effects on wood properties and saccharification efficiency. Phytochemistry 2015, 112, 210-220. [CrossRef] [PubMed]

49. Biswal, A.K.; Hao, Z.; Pattathil, S.; Yang, X.; Winkeler, K.; Collins, C.; Mohanty, S.S.; Richardson, E.A.; Gelineo-Albersheim, I.; Hunt, K.; et al. Downregulation of GAUT12 in Populus deltoides by RNA silencing results in reduced recalcitrance, increased growth and reduced xylan and pectin in a woody biofuel feedstock. Biotechnol. Biofuels 2015, 12, 41. [CrossRef] [PubMed]

50. Biswal, A.K.; Atmodjo, M.A.; Li, M.; Baxter, H.L.; Yoo, C.G.; Pu, Y.; Lee, Y.C.; Mazarei, M.; Black, I.M.; Zhang, J.Y.; et al. Sugar release and growth of biofuel crops are improved by downregulation of pectin biosynthesis. Nat. Biotechnol. 2018, 36, 249-257. [CrossRef] [PubMed]

51. Studer, M.H.; DeMartini, J.D.; Brethauer, S.; McKenzie, H.L.; Wyman, C.E. Engineering of a high-throughput screening system to identify cellulosic biomass, pretreatments, and enzyme formulations that enhance sugar release. Biotechnol. Bioeng. 2010, 105, 231-238. [CrossRef] [PubMed]

52. Studer, M.H.; DeMartini, J.D.; Davis, M.F.; Sykes, R.W.; Davison, B.; Keller, M.; Tuskan, G.A.; Wyman, C.E. Lignin content in natural Populus variants affects sugar release. Proc. Natl. Acad. Sci. USA 2011, 108, 6300-6305. [CrossRef] [PubMed]

53. Decker, S.R.; Syke, R.W.; Turner, G.B.; Lupoi, J.S.; Doepkke, C.; Tucker, M.P.; Schuster, L.A.; Mazza, K.; Himmel, M.E.; Davis, M.F.; Gjersing, E. High-throughput screening of recalcitrance variations in lignocellulosic biomass: Total lignin, lignin monomers, and enzymatic sugar release. J. Vis. Exp. 2015, 103, 1-12. [CrossRef] [PubMed]

54. Rende, U.; Wang, W.; Gandla, M.L.; Jönsson, L.J.; Niittylä, T. Cytosolic invertase contributes to the supply of substrate for cellulose biosynthesis in developing wood. New Phytol. 2017, 214, 796-807. [CrossRef] [PubMed]

55. Pawar, P.M.A.; Ratke, C.; Balasubramanian, V.K.; Chong, S.L.; Gandla, M.L.; Adriasola, M.; Sparrman, T.; Hedenström, M.; Szwaj, K.; Derba-Maceluch, M.; et al. Downregulation of RWA genes in hybrid aspen affects xylan acetylation and wood saccharification. New Phytol. 2017, 214, 1491-1505. [CrossRef] [PubMed]

56. Pawar, P.M.A.; Derba-Maceluch, M.; Chong, S.L.; Gandla, M.L.; Bashar, S.S.; Sparrman, T.; Ahvenainen, P.; Hedenström, M.; Özparpucu, M.; Ruggeberg, M.; et al. In muro deacetylation of xylan affects lignin properties and improves saccharification of aspen wood. Biotechnol. Biofuels 2017, 10, 1-11. [CrossRef] [PubMed]

57. Obudulu, O.; Mähler, N.; Skotare, T.; Bygdell, J.; Abreu, I.N.; Ahnlund, M.; Gandla, M.L.; Petterle, A.; Moritz, T.; Hvidsten, T.R.; et al. A multi-omics approach reveals function of Secretory Carrier-Associated Membrane Proteins in wood formation of Populus trees. BMC Genom. 2018, 19, 11. [CrossRef] [PubMed]

58. Escamez, S.; Gandla, L.M.; Derba-Maceluch, M.; Lundqvist, S.O.; Mellerowicz, E.J.; Jönsson, L.J.; Tuominen, H. A collection of genetically engineered Populus trees reveals wood biomass traits that predict glucose yield from enzymatic hydrolysis. Sci. Rep. 2017, 7, 1-11. [CrossRef] [PubMed]

59. Normark, M.; Winestrand, S.; Lestander, T.A.; Jönsson, L.J. Analysis, pretreatment and enzymatic saccharification of different fractions of Scots pine. BMC Biotechnol. 2014, 14, 20. [CrossRef] [PubMed]

60. Normark, M.; Pommer, L.; Gräsvik, J.; Hedenström, M.; Gorzsás, A.; Winestrand, S.; Jönsson, L.J. Biochemical conversion of torrefied Norway spruce after pretreatment with acid or ionic liquid. Bioenergy Res. 2016, 9 , 355-368. [CrossRef] 
61. Kaku, T.; Kaida, R.; Baba, K.; Hartati, S.; Sudarmonowati, E.; Hayashi, T. Improvement of fermentable sugar yields of mangium through transgenic overexpression of xyloglucanase. J. Wood Sci. 2011, 57, 545-548. [CrossRef]

62. Gomez, L.D.; Whitehead, C.; Barakate, A.; Halpin, C.; McQueen-Mason, S.J. Automated saccharification assay for determination of digestibility in plant materials. Biotechnol. Biofuels 2010, 3, 23. [CrossRef] [PubMed]

63. Gomez, L.D.; Whitehead, C.; Roberts, P.; McQueen-Mason, S.J. High-throughput saccharification assay for lignocellulosic materials. J. Vis. Exp. 2011, 53, 1-5. [CrossRef] [PubMed]

64. Santoro, N.; Cantu, S.L.; Tornqvist, C.E.; Falbel, T.G.; Bolivar, J.L.; Patterson, S.E.; Pauly, M.; Walton, J.D. A high-throughput platform for screening milligram quantities of plant biomass for lignocellulose digestibility. Bioenergy Res. 2010, 3, 93-102. [CrossRef]

65. Berlin, A.; Maximenko, V.; Bura, R.; Kang, K.Y.; Gilkes, N.; Saddler, J. A rapid microassay to evaluate enzymatic hydrolysis of lignocellulosic substrates. Biotechnol. Bioeng. 2006, 93, 880-886. [CrossRef] [PubMed]

66. Van Acker, R.; Vanholme, R.; Storme, V.; Mortimer, J.C.; Dupree, P.; Boerjan, W. Lignin biosynthesis perturbations affect secondary cell wall composition and saccharification yield in Arabidopsis thaliana. Biotechnol. Biofuels 2013, 6, 46. [CrossRef] [PubMed]

67. Van Acker, R.; Lepléc, J.-C.; Aerts, D.; Storme, V.; Goeminne, G.; Ivens, B.; Légéee, F.; Lapierree, C.; Piens, K.; Van Montagua, M.C.E.; et al. Improved saccharification and ethanol yield from field-grown transgenic poplar deficient in cinnamoyl-CoA reductase. Proc. Natl. Acad. Sci. USA 2014, 111, 845-850. [CrossRef] [PubMed]

68. Wolfrum, E.J.; Ness, R.M.; Nagle, N.J.; Peterson, D.J.; Scarlata, C.J. A laboratory-scale pretreatment and hydrolysis assay for determination of reactivity in cellulosic biomass feedstocks. Biotechnol. Biofuels 2013, 6, 162. [CrossRef] [PubMed]

69. Chundawat, P.S.; Venkatesh, B.; Dale, B.E. High-throughput microplate technique for enzymatic hydrolysis of lignocellulosic biomass. Biotechnol. Bioeng. 2008, 99, 1281-1294. [CrossRef] [PubMed]

70. Selig, M.J.; Tucker, M.P.; Sykes, R.W.; Reichel, K.L.; Brunecky, R.; Himmel, M.E.; Davis, M.F.; Decker, S.R. Lignocellulose recalcitrance screening by integrated high-throughput hydrothermal pretreatment and enzymatic saccharification. Ind. Biotechnol. 2010, 6, 104-111. [CrossRef]

71. Ratke, C.; Terebieniec, B.K.; Winestrand, S.; Derba-Maceluch, M.; Grahn, T.; Schiffthaler, B.; Ulvcrona, T.; Özparpucu, M.; Ruggeberg, M.; Lundqvist, S.O.; et al. Downregulating aspen xylan biosynthetic GT43 genes in developing wood stimulates growth via reprograming of the transcriptome. New Phytol. 2018, 219, 230-245. [CrossRef] [PubMed]

72. Li, H.; Gao, X.; DeMartini, J.D.; Kumar, R.; Wyman, C.E. Application of high throughput pretreatment and co-hydrolysis system to thermochemical pretreatment. Part 2: Dilute alkali. Biotechnol. Bioeng. 2013, 110, 2894-2901. [CrossRef] [PubMed]

73. Gräsvik, J.; Winestrand, S.; Normark, M.; Jönsson, L.J.; Mikkola, J.P. Evaluation of four ionic liquids for pretreatment of lignocellulosic biomass. BMC Biotechnol. 2014, 14, 34. [CrossRef] [PubMed]

74. Zavrel, M.; Bross, D.; Funke, M.; Buchs, J.; Spiess, A.C. High-throughput screening for ionic liquids dissolving (ligno-) cellulose. Bioresour. Technol. 2009, 100, 2580-2587. [CrossRef] [PubMed]

75. Miller, G.L. Use of dinitrosalicylic acid reagent for determination of reducing sugar. Anal. Chem. 1959, 31, 426-428. [CrossRef]

76. Bailey, M.J. A note on the use of dinitrosalicylic acid for determining the products of enzymatic reactions. Appl. Microbiol. Biotechnol. 1988, 29, 494-496. [CrossRef]

77. Nelson, N. A photometric adaptation of the Somogyi method for the determination of glucose. J. Biol. Chem. 1944, 153, 375-380.

78. Walker, J.M. The bicinchoninic acid (BCA) assay for protein quantitation. In The Protein Protocols Handbook; Walker, J.M., Ed.; Humana Press: Totowa, NJ, USA, 2009; pp. 11-15.

79. Anthon, G.E.; Barrett, D.M. Determination of reducing sugars with 3-methyl-2- benzothiazolinonehydrazone. Anal. Biochem. 2002, 305, 287-289. [CrossRef] [PubMed]

80. Bergmeyer, H.U.; Bernt, E. D-Glucose determination with glucose oxidase and peroxidase. In Methods of Enzymatic Analysis; Bergmeyer, H.U., Ed.; Verlag Chemie: Weinheim, Germany, 1974; pp. 1205-1215.

81. Kunst, A.; Draeger, B.; Ziegenhorn, J. UV-methods with hexokinase and glucose-6-phosphate dehydrogenase. In Methods of Enzymatic Analysis; Bergmeyer, H.U., Ed.; Verlag Chemie: Weinheim, Germany, 1984; pp. 163-172. 
82. Hildén, L.; Eng, L.; Johansson, G.; Lindqvist, S.E.; Pettersson, G. An amperometric cellobiose dehydrogenase-based biosensor can be used for measurement of cellulase activity. Anal. Biochem. 2001, 290, 245-250. [CrossRef] [PubMed]

83. Feng, J.; Himmel, M.E.; Decker, S.R. Electrochemical oxidation of water by a cellobiose dehydrogenase from Phanerochaete chrysosporium. Biotechnol. Lett. 2005, 27, 555-560. [CrossRef] [PubMed]

84. Hale, P.D.; Boguslavsky, L.I.; Inagaki, T.; Karan, H.I.; Lee, H.S.; Skotheim, T.A.; Okamoto, Y. Amperometric glucose biosensors based on redox polymer-mediated electron transfer. Anal. Chem. 1991, 63, 677-682. [CrossRef]

85. Silva, A.S.A.; Souza, M.F.; Ballesteros, I.; Manzanares, P.; Ballesteros, M.; Bon, E.P.S. High-solids content enzymatic hydrolysis of hydrothermally pretreated sugarcane bagasse using a laboratory-made enzyme blend and commercial preparations. Process Biochem. 2016, 51, 1561-1567. [CrossRef]

86. Black, G.E.; Fox, A. Recent progress in the analysis of sugar monomers from complex matrices using chromatography in conjunction with mass spectrometry or stand-alone tandem mass spectrometry. J. Chromatogr. 1996, 720, 51-60. [CrossRef]

87. Khandurina, J.; Olson, N.A.; Anderson, A.A.; Gray, K.A.; Guttman, A. Large-scale carbohydrate analysis by capillary array electrophoresis: Part 1. Separation and scale-up. Electrophoresis 2004, 25, 3117-3121. [CrossRef] [PubMed]

(C) 2018 by the authors. Licensee MDPI, Basel, Switzerland. This article is an open access article distributed under the terms and conditions of the Creative Commons Attribution (CC BY) license (http:/ / creativecommons.org/licenses/by/4.0/). 